\title{
PREFERENSI PADA MEDIA PENELURAN DAN PEMBERIAN PAKAN TERHADAP PRODUKSI TELUR Sexava nubila STAL. (ORTHOPTERA; TETTIGONIDAE)
}

\author{
MEDIA NESTING PREFERENCES AND GRANT OF FEED PRODUCTION OF EGGS Sexava \\ nubila STAL. (ORTHOPTERA; TETTIGONIDAE)
}

\author{
Dinda Grace Buambitun'), Christina L. Salaki'2), Jusuf Manueke' ${ }^{2)}$ dan Moulwy F. Dien ${ }^{3)}$ \\ 1)Alumni Fakultas Pertanian Universitas Sam Ratulangi, Manado \\ 2)Fakultas Pertanian Universitas Sam Ratulangi, Manado \\ 3)Perhimpunan Entomologi Indonesia (PEI), cabang Manado \\ e-mail: dgbuambitun@yahoo.com
}

\begin{abstract}
The study aims to determine the effect of the combination of feeding and spawning media against $S$. nubila egg productivity has been carried out in the Laboratory of Biological Plantation Office, Village Lobbo, North Beo District of Talaud Islands. held for 4 months ie from January to April 2015. Research using completely randomized design (CRD) with treatments that $(A)$ Media dry sand, $(B)$ Media moist sand (C) Media dry soil, (D) Media soil moist, (E) Media mix of soil and sand to dry, (F) Media mixture of soil and sand moist. $(G)$ Each treatment was repeated 4 times. Testing feeding consists of treatment $(A)$ Coconut leaves, (B) Banana leaves, (C) Combination of palm leaves + banana leaves, (D) Reed. The results showed that the highest egg production was found in Coconut leaves + combination treatment of Banana leaves which reached an average of 50.13 grains followed by treatment Coconut leaves of the grain 36.25 , banana leaves 27.11 grain treatment, and treatment reeds 0,06 grains. Observation of oviposition or the laying of eggs by female imago highest turns found in moist sand treatment media, reaching an average of 31.71 grains, kemuadian consecutive dry sand media average of 25.47 grains, sand + soil moist average of 23,64 grain, moist soil on average 21.16 grains, dry ground Sand + average 18.66 and the lowest point on dry land media average of 15.7 grains

Keywords: Sexava nubila, Preferences and production of egg
\end{abstract}

\section{ABSTRAK}

Penelitian bertujuan untuk mengetahui pengaruh pemberian kombinasi pakan dan media peneluran terhadap produktifitas telur S. nubila telah dilaksanakan di Laboratorium Hayati Dinas Perkebunan, Desa Lobbo, Kecamatan Beo Utara Kabupaten Kepulauan Talaud. dilaksanakan selama 4 bulan yakni sejak bulan Januari sampai dengan April 2015. Penelitian menggunakan metode Rancangan Acak Lengkap (RAL) dengan perlakuan yaitu (A) Media pasir kering, $(B)$ Media pasir lembab (C) Media tanah kering, (D) Media tanah lembab, (E) Media campuran tanah dan pasir kering, (F) Media campuran tanah dan pasir lembab. (G) Masing-masing perlakuan diulang sebanyak 4 kali. Pengujian pemberian pakan terdiri dari perlakuan (A) Daun kelapa, (B) Daun pisang, (C) Kombinasi daun kelapa + daun pisang, (D) Alang-alang. Hasil penelitian menunjukkan bahwa peletakkan telur oleh imago betina ternyata tertinggi dijumpai pada perlakuan media pasir lembab yakni mencapai rata-rata 31,71 butir, kemudian berturut-turut media pasir kering rata-rata 25,47 butir, Pasir + Tanah lembab rata-rata 23,64 butir, Tanah lembab rata-rata 21,16 butir, Pasir + tanah kering rata-rata 18,66 butir dan terendah pada media tanah kering rata-rata 15,7 butir. Pengamatan terhadap uji pemberian pakan menunjukkan bahwa produksi telur tertinggi dijumpai pada perlakuan kombinasi pakan daun kelapa + daun pisang yakni mencapai rata-rata 50,13 butir kemudian diikuti oleh perlakuan daun kelapa 36,25 butir, perlakuan daun pisang 27,11 butir, perlakuan alang-alang 0,06 butir, dan tanpa pakan (kontrol) 0,00 butir.

Kata kunci : Sexava nubila, preferensi dan produksi telur

Eugenia Volume 21 No. 2 Juni 2015 


\section{PENDAHULUAN}

Kelapa masih merupakan salah satu tanaman industri andalan bagi daerah Provinsi Sulawesi Utara karena memberikan kontribusi dalam pendapatan daerah di sektor pertanian termasuk Kabupaten Kepulauan Talaud. Hasil-hasil kelapa seperti daging, air, tempurung, sabuk, batang dan produk-produk lainnya masih dapat ditingkatkan dengan pemanfaatan teknologi modern untuk memberikan nilai tambah bagi petani dan sekaligus meningkatkan pendapatan daerah. Selain itu, kelapa juga merupakan komoditas strategis dalam perekonomian bangsa Indonesia, terutama sebagai penghasil minyak nabati dan sumber pendapatan bagi petani serta keperluan ekspor. Dewasa ini dengan adanya krisis minyak bumi, peranan kelapa semakin penting karena dapat digunakan sebagai bahan baku biodiesel (Wagiman, dkk., 2012).

Pada umumnya produksi kelapa masih sangat dibatasi oleh adanya hama dan penyakit, selain karena banyak tanaman kelapa yang sudah tua (berumur lebih dari 60 tahun) sehingga menurunkan produksinya. Hama belalang kelapa, Sexava nubila (Orthoptera: Tettigonidae) merupakan salah satu hama penting yang sangat merusak tanaman kelapa terutama di Indonesia Timur termasuk di Kabupaten Kepulauan Talaud, Provinsi Sulawesi Utara. Hama belalang kelapa ini memang sudah sejak awal tahun 1920-an telah menjadi hama penting yang merusak tanaman kelapa dan menurunkan produksi kelapa di daerah ini. Hama S. nubila pertama-tama dilaporkan oleh Leefman, yang menyerang tanaman kelapa di Kabupaten Kepulauan Talaud (Leefmans, 1927 dalam Sembel $d k k ., 2013)$.

Terdapat tiga spesies Sexava yaitu $S$. coriaceae L. dijumpai di Maluku, Sulawesi Timur, Kepulauan Sangir dan Papua Utara; S. nubila Stall. ditemukan di Kei, Kepulauan Aru, Seram, Batjan, Talaud dan Kepulauan Nanusa serta Irian; $S$. karnyi Leefman terdapat di Tomini dan Sulawesi Selatan (Kalshoven, 1981).

Sejak tahun 1990-an belalang kelapa ini juga sudah dilaporkan menyerang tanaman kelapa di daerah Bolaang Mongondow tetapi tingkat serangannya kurang dan belum mengakibatkan kerusakan yang berarti pada tanaman kelapa.

S. nubila adalah sejenis belalang yang merupakan hama penting pada tanaman kelapa di Kabupaten Kepulauan Talaud. Selain menyerang daun, hama ini juga menyerang tangkai buah yang masih kecil sehingga buah tidak berkembang ataupun jatuh. Secara fisiologi kerusakan daun yang terjadi akan mempengaruhi proses pertumbuhan tanaman tersebut. Hal ini berarti bahwa kerusakan daun yang terjadi akibat serangan hama ini akan menentukan kemampuan tanaman kelapa untuk berproduksi. Jatuhnya buah mudah akibat gerekan nimfa maupun imago hama ini berdampak pada rendahnya produksi yang dihasilkan.

Padat populasi S. nubila pada tanaman kelapa di Kabupaten Kepulauan Talaud berfluktuasi menurut keadaan lingkungan hidupnya dan telah menimbulkan kerugian ekonomi dari tahun ke tahun. Akibat serangan hama ini secara langsung mempengaruhi ekonomi dan sosial politik masyarakat di wilayah sebaran hama tersebut, karena sebagian petani menebang tanaman kelapa yang masih produktif dan menggantinya dengan jenis tanaman lainnya, sebagian penduduk terpaksa berpindah ke tempat lain untuk mencari nafkah (Alouw dan Hosang, 2005; Wagiman dkk., 2012).

Penelitian ini bertujuan untuk mengetahui pengaruh pemberian kombinasi pakan terhadap produktifitas telur $S$. nubila.

Hasil penelitian diharapkan dapat digunakan sebagai bahan pertimbangan dalam penyusunan program pengendalian hama $S$. nubila di masa yang akan datang.

\section{METODE PENELITIAN}

Penelitian dilaksanakan di Laboratorium Hayati Dinas Perkebunan, Desa Lobbo, Kecamatan Beo Utara Kabupaten Kepulauan Talaud. Penelitian dilaksanakan selama 4 bulan yakni sejak bulan Januari sampai dengan April 2015.

Penelitian menggunakan metode Rancangan Acak Lengkap (RAL) yang masingmasing perlakukan diulang sebanyak 4 kali. 


\section{Prosedur Kerja \\ Persiapan}

Persiapan adalah kegiatan mempersiapkan bahan dan alat yang akan digunakan dalam penelitian diantaranya penyiapan.

\section{Kotak Kurungan Kasa}

Kotak kurungan kasa berukuran 1,5 $\mathrm{m} x$ $1,5 \mathrm{~m} \times 1,5 \mathrm{~m}$ dibuat dari rangka kayu yang sekelilingnya ditutupi dengan kawat kasa. Kotak kurungan kasa digunakan untuk perbanyakan $S$. nubila dan Preferensi oviposisi dan lama hidup $S$. nubila Stall (Orthoptera;Tettigonidae) terhadap jenis pakan dan media peneluran.

\section{Penangkapan Nimfa S. nubila}

Nimfa S. nubila ditangkap pada tanaman kelapa di sekitar lokasi penelitian. Nimfa yang tertangkap dipelihara di kotak kurangan kasa sampai menjadi imago. Imago disortir kemudian dimasukkan ke dalam kotak kurungan kasa dengan perbandingan 2 jantan dan 3 betina dan diberi makan sesuai perlakukan.

Hal-hal yang diamati dalam penelitian ini adalah :

\section{Percobaan Penggunaan Media Peneluran terhadap Produksi Telur S. nubila}

Setelah imago di rearing berdasarkan perlakuan pakan, kemudian di dalam masingmasing kotak kurungan kasa diletakkan media peneluran yang diletakkan pada nampan plastik. Perlakuan media peneluran adalah (A) pasir kering, (B) pasir lembab, (C) tanah kering, (D) tanah lembab, $(E)$ campuran pasir + tanah kering, dan $(F)$ campuran pasir + tanah lembab dengan memasukkan media sesuai perlakuan ke dalam kotak kurungan. Masing-masing media diletakkan pada wadah nampan plastik. Nampan diangkat setiap hari untuk diamati apakah terdapat telur, kemudian telur yang ditemukan dihitung jumlahnya. Kegiatan pengamatan jumlah telur dapat dilihat pada Gambar 1. Untuk menghitung rata-rata telur yang diletakkan oleh imago betina pada media digunakan rumus :

Rata-rata populasi telur $=\frac{\text { jumlah telur } \text { yang diletakkan }}{\text { jumlah } \text { imago betina }}$

\section{Percobaan Jenis Pakan terhadap Produksi Telur S. nubila}

Setelah menjadi imago diinfestasikan ke dalam kotak rearing dengan perbandingan dua ekor jantan dan tiga ekor betina. Imago diberi pakan daun sesuai perlakuan yaitu (A) Daun Kelapa, (B) Daun Pisang, (C) Kombinasi Daun kelapa + Daun Pisang, dan (D) Alang-alang. Pakan diganti dengan pakan segar setiap hari. Kegiatan perbanyakan $S$. nubila dapat dilihat pada Gambar 2.

\section{Lama Hidup Imago S. nubila}

Pengamatan lama hidup hanya dilakukan pada imago betina. Imago diinfestasikan ke dalam kotak kurungan berdasarkan perlakuan pemberian pakan dan media peneluran. Pakan diganti setiap hari dengan pakan yang segar. Pengamatan dilakukan setiap hari sejak imago diinfestasikan ke dalam kotak/kurungan kasa sampai imago mati. Imago yang mati segera dikeluarkan dan dicatat tanggal kematiaannya agar dapat diketahui lama hidup imago.

\section{HASIL DAN PEMBAHASAN}

\section{Oviposisi Sexava nubila Terhadap Media Peneluran}

Hasil analisis sidik ragam pengaruh perlakuan terhadap jumlah telur yang diletakkan oleh imago betina $S$. nubila pada berbagai media menunjukkan pengaruh yang sangat nyata. Hasil pengamatan terhadap preferensi media peneluran oleh imago betina ternyata tertinggi dijumpai pada perlakuan media pasir lembab (pasir yang dibasahi) yakni mencapai rata-rata 31,71 butir, dan terendah pada perlakuan media tanah kering rata-rata 15,7 butir, selengkapnya disajikan pada Tabel 1 . 


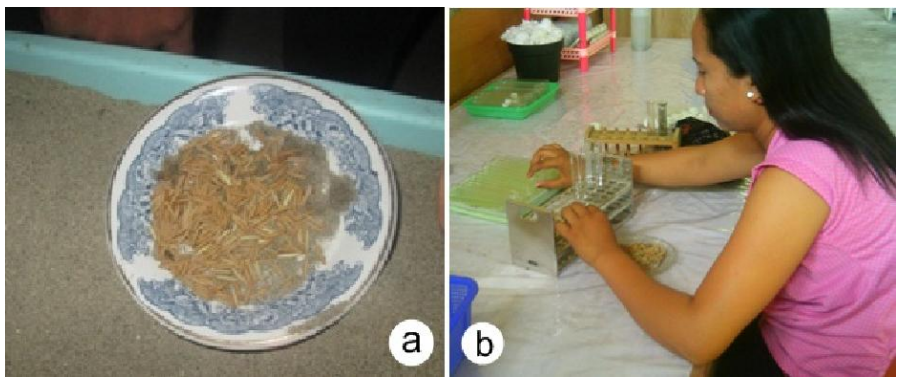

Gambar 1. Pengamatan jumlah telur pada media peneluran

a. Sejumlah telur S. nubila

b. Penghitungan jumlah telur
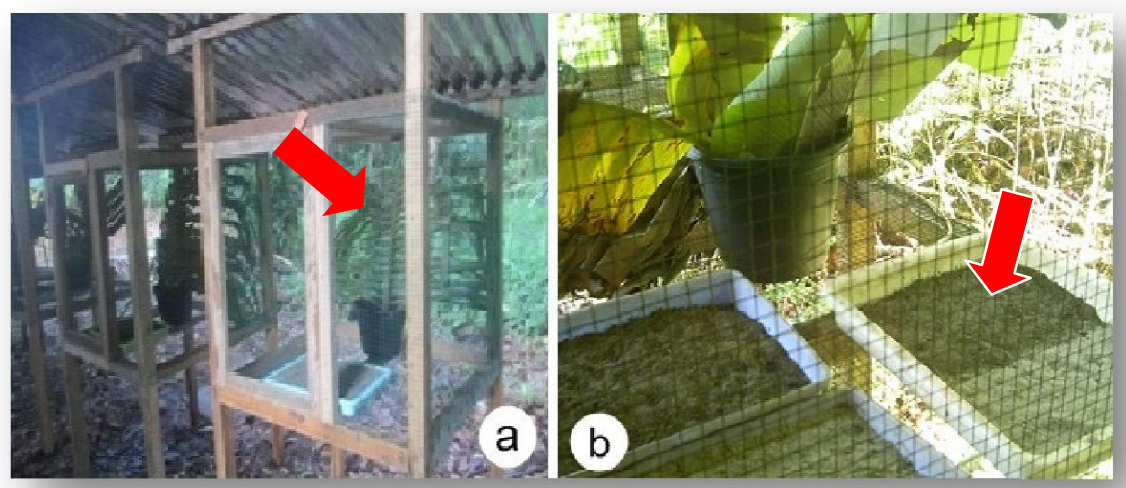

Gambar 2. Kegiatan perbanyakan S. nubila

Keterangan : (a) uji pengaruh pemberian pakan

(b) uji pengaruh media peneluran

Tabel 1. Rata-rata jumlah telur yang diletakkan oleh imago betina pada berbagai media

\begin{tabular}{|c|c|c|c|c|c|c|c|}
\hline & Perlakuan & Rataan telur (butir) & & & Notasi *) & & \\
\hline$B$ & (Tanah kering) & 15,64 & $\mathrm{a}$ & & & & \\
\hline C & (Pasir + Tanah kering) & 18,66 & & b & & & \\
\hline $\mathrm{E}$ & (Tanah lembab / dibasahi) & 21,16 & & & c & & \\
\hline $\mathrm{F}$ & (Pasir + Tanah lembab / dibasahi) & 23,64 & & & & d & \\
\hline A & (Pasir kering) & 25,47 & & & & d & \\
\hline D & (Pasir lembab / dibasahi) & 31,71 & & & & & e \\
\hline
\end{tabular}

*) Angka yang diikuti dengan huruf yang sama menunjukkan tidak berbeda nyata (BNT 5\% = 2,46)

Preferensi pemilihan tempat untuk melakukan oviposisi oleh serangga biasanya ditentukan oleh alat-alat sensori yang terdapat pada ovipositor. Rambut-rambut halus yang terdapat pada ovipositor merupakan salah satu alat sensori yang dapat mendeteksi keadaan inangnya baik dari segi nutrisi ataupun suhu dan kelembaban di sekitar inangnya. Beberapa serangga memerlukan panas tertentu dan ataupun kelembaban tertentu untuk membantu proses penetasan telur. Penetasan telur menjadi nimfa $S$. nubila sangat rendah pada media tanah kering. Hasil penelitian Dien dan Dumalang (2010) melaporkan bahwa pada kondisi media tanah yang kering, kurang lebih $60-80 \%$ telur $S$. nubila tidak menetas menjadi nimfa. 


\section{Oviposisi Sexava nubila pada Beberapa Jenis Pakan}

Analisis sidik ragam pengaruh pakan terhadap produksi telur imago betina $S$. nubila menunjukkan pengaruh yang sangat nyata. Hasil penelitian menunjukkan bahwa rata-rata produksi telur tertinggi dijumpai pada perlakuan kombinasi daun kelapa + daun pisang yakni mencapai rata-rata 50,13 butir kemudian diikuti oleh perlakuan daun kelapa 36,25 butir, perlakuan daun pisang 27,11 butir, perlakuan alang-alang 0,06 butir (Tabel 2).

Data pada Tabel 2 menunjukkan bahwa keempat perlakuan menunjukkan perbedaan terhadap rataan telur yang dihasilkan oleh imago betina $S$. nubila. Perlakuan pemberian pakan berupa kombinasi daun kelapa + daun pisang menghasilkan rata-rata produksi telur yang paling tinggi dibandingkan dengan perlakuan pemberian pakan lainnya. Hal ini karena kombinasi pakan daun kelapa + daun pisang diduga memiliki nutrisi yang sesuai bagi perkembangan $S$. nubila.

Produksi telur akan sangat tergantung pada nutrisi tanaman inang terutama kadar protein dan asam-asam aminonya. Daun pisang memiliki kadar air yang lebih tinggi dan lebih lembut serta jauh lebih lebar dibandingkan dengan daun kelapa. Daun pisang juga mengandung nilai gizi yang lebih baik dibandingkan dengan alang-alang. Rendahnya peletakan telur $S$. nubila pada alang-alang menunjukkan bahwa gizi alang-alang tidak sesuai untuk perkembangan hama S. nubila (Sembel, $d k k$., 2013). Serangga diketahui memiliki kemampuan untuk dapat mendeteksi kandungan gizi dari suatu tanaman. Bila kandungan gizinya tidak sesuai dan apalagi tanaman tersebut mengandung senyawa yang tidak cocok (racun) untuk perkembangan serangga maka serangga tersebut tidak akan meletakkan telur pada tanaman tersebut. Alang-alang tersedia dalam jumlah yang cukup namun memiliki nilai nutrisi yang lebih rendah daripada daun kelapa dan pisang. Selain itu struktur morfologi bagian luar dari alang-alang memiliki bulu-bulu yang keras dan kasar serta kadar serat yang lebih tinggi dibandingkan dengan daun pisang dan daun kelapa yang lebih lembut, kadar serat yang lebih rendah dan tanpa memiliki bulu-bulu serta pinggiran daun yang tajam. Selain itu alang-alang memiliki daun yang langsing dimana hama $S$. nubila yang berukuran tubuh besar dan memiliki antena yang panjang tidak secara gampang bertengger di atas permukaan daun alang-alang seperti halnya daun kelapa yang kuat dan daun pisang yang besar dan lebar (Sembel, dkk., 2013).

Suatu tanaman akan menjadi inang dari suatu hama tertentu manakala serangga hama menemukan inang itu kemudian meletakkan telur, menetas menjadi larva atau nimfa dan melangsungkan kehidupan sepenuhnya dan satu siklus penuh dengan makan tanaman inang tersebut. Tingkat pertumbuhan serangga hama yang makan yaitu larva atau nimfa dan imago dapat melangsungkan hidup dengan makan tanaman inang yang bergizi serta tidak menghasilkan senyawa yang dapat membahayakan kelangsungan hidup hama serangga tersebut.

Pedigo (2005) menyatakan bahwa hubungan pemilihan inang bagi serangga melewati 5 tahap yaitu penemuan habitat, penemuan Inang, pengenalan inang, penerimaan inang, dan kesesuaian inang. Pemilihan inang oleh serangga ditentukan oleh nilai nutrisi yang tersedia dan serta ada tidaknya toksin (racun) bagi serangga hama yang terkandung dalam tanaman (Anonim, 2013; Hadianirahmi, 2009).

Tabel 2. Rata-rata Telur yang dihasilkan pada Berbagai Perlakuan Pemberian Pakan

\begin{tabular}{ccc}
\hline Perlakuan & Rataan telur (butir) & Notasi $^{\star}$ ) \\
\hline D (Alang-alang) & 0,06 & $\mathrm{a}$ \\
B (Daun Pisang) & 27,11 & $\mathrm{~b}$ \\
A (Daun Kelapa) & 36,25 & $\mathrm{c}$ \\
C (Daun Kelapa+Daun Pisang) & 50,13 & $\mathrm{~d}$ \\
\hline${ }^{*}$ ) Angka yang diikuti dengan huruf yang sama menunjukkan tidak berbeda nyat (BNT 5\% $\left.=237\right)$
\end{tabular}

$\left.{ }^{*}\right)$ Angka yang diikuti dengan huruf yang sama menunjukkan tidak berbeda nyata (BNT 5\% $=2,37$ ) 


\section{Lama Hidup Sexava nubila pada Beberapa Jenis Pakan}

Rata-rata lama hidup imago $S$. nubila bervariasi menurut jenis pakan yang diberikan. Pada perlakuan pemberian pakan daun kelapa + daun pisang lama hidup imago mencapai 80 - 93 hari, perlakuan pemberian pakan daun kelapa $67-83$ hari, perlakuan pembarian pakan daun pisang 75,77 hari, perlakuan pemberian pakan alang-alang 16 - 34 hari. Pada perlakuan pemberian pakan kombinasi daun kelapa dan daun pisang menyebabkan lama hidup imago lebih lama dibandingkan dengan perlakuan lain, hal ini diduga karena pada kedua jenis makanan ini mengandung sejumlah nutrisi yang dibutuhkan untuk perkembangan hama S. nubila.

Sembel, dkk. (2013) menyatakan bahwa produksi telur akan sangat tergantung pada nutrisi tanaman inang terutama kadar protein dan asamasam aminonya. Daun pisang memiliki kadar air yang lebih tinggi dan lebih lembut serta jauh lebih lebar dibandingkan dengan daun kelapa. Daun pisang juga mengandung nilai gizi yang lebih baik dibandingkan dengan alang-alang. Rendahnya peletakan telur S. nubilla pada alang-alang menunjukkan bahwa gizi alang-alang tidak sesuai untuk perkembangan hama $S$. nubilla. Serangga diketahui memiliki kemampuan untuk dapat mendeteksi kandungan gizi dari suatu tanaman. Manakala kandungan gizinya tidak sesuai dan apalagi tanaman tersebut mengandung senyawa yang tidak cocok (racun) untuk perkembangan serangga maka serangga tersebut tidak akan meletakkan telur pada tanaman tersebut. Memang terkadang serangga dapat meletakkan telurnya tetapi pada akhirnya telur akan mengering dan mati atau telur akan menetas tapi nimfa atau larvanya tidak akan dapat bertahan hidup dan mati karena kandungan gizi tanaman yang tidak sesuai.

Kandungan nutrisi yang cukup dan sesuai akan menyebabkan optimalisasi pertumbuhan dan perkembangannya. Walaupun jumlah makanan berlimpah namun jumlah nutrisi yang diperoleh dalam makanan sangat terbatas ataupun tidak sesuai maka perkembangan dapat saja berjalan terus namun pertumbuhannya tidak sempurna.

\section{KESIMPULAN DAN SARAN}

\section{Kesimpulan}

Oviposisi Sexava nubila pada beberapa media peneluran tertinggi ditemukan pada media pasir lembab/dibasahi mencapai rata-rata 31,71 butir/ekor imago betina, pasir + tanah lembab/ dibasahi 23,64 butir/ekor imago betina, pasir kering 25,47 butir/ekor imago betina, tanah lembab/ dibasahi 21,16 butir/ekor imago betina, pasir + tanah kering 18,66 butir/ekor imago betina, dan tanah kering 15,64 butir/ekor imago betina.

Preferensi oviposisi $S$. nubila pada beberapa jenis pakan berupa kombinasi daun kelapa dan daun pisang segar menghasilkan produksi telur tertinggi yakni mencapai rata-rata 50,13 butir/ekor imago betina, perlakuan pakan daun kelapa 36,25 butir/ekor imago betina, perlakuan pakan daun pisang 27,11 butir/ekor imago betina dan perlakuan pakan alang-alang 0,06 butir/ekor imago betina.

Lama hidup imago $S$, nubila pada beberapa jenis pakan tertinggi ditemukan pada perlakuan daun kelapa + daun pisang yakni mencapai $80-93$ hari. Perlakuan pemberian pakan daun kelapa 67 83 hari, perlakuan pemberian pakan daun pisang 75,77 hari, perlakuan pemberian pakan alang-alang $16-34$ hari.

\section{Saran}

Perlu penelitian lanjutan untuk mengetahui pengaruh pemberian pakan terhadap sex ratio $S$. nubila.

\section{DAFTAR PUSTAKA}

Alouw J. dan M. L. A. Hosang. 2005. Pengaruh Iklim terhadap Populasi Sexava spp. Monograf Hama dan Penyakit kelapa. Balai Penelitian dan Pengembangan Pertanian. Pusat Penelitian dan Pengembangan Perkebunan. Balai Penelitian Tanaman Kelapa dan Palma Lainnya, Manado.

Hadianirahmi, 2009. Hubungan Serangga dan Tanaman Inang. https://hadianirahmi. 
wordpress.com/2009/10/27/hubungan-

serangga-dan-tanaman-inang

Kalshoven, L. G. E. 1981. Pests of Crops in Indonesia. Revised and Translated by P.A Van der Laan. P.T. Ichtiar Baru - van Hoove, Jakarta.

Pedigo, L.P. 2005. Entomology and Pest Management. Prentice-Hall of India, New Delhi.

Sembel, D. T., M. F. Dien, C. S. Rante, M. M. Ratulangi, E. R. M. Meray dan D. S. Kandowangko. 2013. Status Musuhmusuh Alami dan Pemanfaatannya untuk Pengendalian Hayati Hama Sexava spp di Kabupaten Kepulauan Talaud. Kerjasama Tim Peneliti Fakultas Pertanian Unsrat dengan Badan Penelitian dan Pengembangan Kabupaten Kepulauan Talaud.
Wagiman, F. X., M. L. A. Hosang dan F. Lala, 2012. Analisis Respons Kelapa Terhadap Serangan Hama Sexava dan Pengembangan Skoring Kerusakan Di Kabupaten Kepulauan Talaud. Penelitian Kerjasama Institusi Tahun Anggaran 2012, Direktorat Jenderal Pendidikan Tinggi. Departemen Pendidikan dan Kebudayaan. 